\title{
KONFLIK PADA MASYARAKAT NELAYAN PANTAI UTARA JAWA BARAT (STUDI KASUS : DI DESA ERETAN WETAN KECAMATAN KANDANGHAUR KABUPATEN INDRAMAYU
}

\author{
Oleh: \\ Soni A. Nulhaqim, Maulana Irfan, \\ Wandi Adiansah \\ (soni.nulhaqim@unpad.ac.id, maulana.irfan@unpad.ac.id, adiansahw@gmail.com)
}

\begin{abstract}
ABSTRAK
Konflik merupakan satu fenomena yang tejadi sebagai bagian dari dinamika sebuah masyarakat. Konflik yang terjadi dalam sebuah masyarakat akan menimbulkan berbagai kerugian bagi masyarakat. Penelitian ini mengangkat konflik di Pantai Utara dengan kondisi geografis, karakteristik penduduk dan profesi penduduk yang mayoritas merupakan nelayan. Daerah yang diteliti adalah daerah rawan konflik yaitu di Desa Eretan Wetan Kec. Kandanghaur, Kab. Indramayu.Jenis penelitian yang digunakan yaitu deskriptif, melalui Pendekatan kualitatif dan studi kasus. Informan penelitian ini adalah para pelaku konflik dengan teknik pengumpulan data yang digunakan adalah wawancara mendalam dan observasi nonpartisipasi serta kajian dokumentasi.

Konflik di Desa Eretan Wetan terjadi beberapa konflik baik konflik dalam skala besar maupun skala kecil. Konflik ini juga terjadi baik pada masyarakat umum maupun pada masyarakat nelayan. Pada masyarakat umum, konflik yang pernah terjadi yaitu konflik pesta laut, konflik dengan salah satu perusahaan, konflik antar pemuda, konflik antar keluarga, konflik yang terkai ISIS, konflik antar etnis dan konflik berkenaan BLT. Sedangkan konflik masyarakat nelayan yaitu konflik alat tangkap ikan, konflik nelayan dengan juragan, konflik antara nelayan dengan pemilik industri pengolahan ikan dan juga konflik antara nelayan tradisional dengan konsumen. Konflik yang terjadi baik pada masyarakat umum maupun nelayan dipicu karena adanya provokator dan adanya masalah diantara pihak yang berkonflik. Konflik disebabkan karena adanya rasa ketidakadilan. Dampak konflik yang terjadi yaitu berupa korban luka/jiwa, kerusakan lingkungan/bangunan, hambatan ekonomi, berkurangnya kepercayaan masyarakat terhadap permerintah dan perubahan nilai budaya. Konflik diselesaikan dengan cara damai dengan menggunakan upaya non ligitasi seperti mediasi dan negosiasi yang difasilitasi oleh tokoh masyarakat, aparat pemerintah/keamanan dan masyarakat secara langsung.
\end{abstract}

Kata kunci : konflik sosial, resolusi konfli 


\section{PENDAHULUAN}

Penelitian tentang konflik di pantai Utara Jawa Barat cukup beralasan, mengingat konflik yang terjadi berkaitan dengan berbagai aspek yaitu adanya benturan nilai, ide atau ideologis dan agama; adanya perbedaan kepentingan yang diusung oleh para pesaing kekuasaan dan adanya kondisi sumberdaya yang terbatas sehingga menjadi bahan rebutan yang menyebabkan konflik $^{10}$. Fenomena tersebut nampak pada kasus persaingan buruh dan majikan/industri, sumber daya air, sumberdaya lahan, pemilihan kepala pemerintahan dan politik, serta konflik ideologis termasuk konflik antar umat beragama. Peristiwa konflik tersebut terkait juga dengan kondisi masyarakat pantai Utara yang cenderung terbuka dan dalam berbagai hal kehidupan sosial budaya.

Salah satu wilayah yang rawan konflik di Provinsi Jawa Barat adalah kawasan pantai Utara. Kawasan pantai Utara (Pantura) Jawa Barat dapat dikatakan rawan konflik karena memiliki karakteristik yang berbeda dengan kawasan lain di Jawa Barat. Jumlah nelayan di Provinsi Jawa Barat sampai pada Tahun 2012 adalah 103.721 orang. Dari jumlah tersebut, sebaran jumlah nelayan yang paling banyak adalah di wilayah Pantai Utara Jawa Barat, yaitu di Kabupaten Indramayu dengan jumlah sebesar 44.515 nelayan. Dengan sebaran terbanyak tersebut nelayan di Pantura masih merupakan nelayan small scale fishery atau nelayan kecil, yaitu pemilik perahu yang sebagian besar penghasilannya bergantung pada kegiatan penangkapan ikan di laut, dan menjual hasil tangkapan ikan dalam lingkup pasar lokal yang terbatas ${ }^{11}$.

Karakteristik wilayah Utara Jawa Barat merupakan wilayah utama dalam pengembangan wilayah industri dan merupakan wilayah utama jalur transportasi darat di Pulau Jawa. Semakin berkembangnya industri di wilayah Utara Jawa Barat,

\footnotetext{
${ }^{10}$ (Wallace and Wolf, 2005).

${ }^{11}$ (Berkes et al (2001), Charles (2001), Satria (2002), Luky(2007)) dalam Prihandoko, dkk (Jurnal Makara,
}

menyebabkan semakin mudah dan besarlah gesekan sosial yang terjadi di masyarakat pantura yang dapat menyebabkan terjadinya konflik sosial. Kemudian isu-isu seperti kemiskinan maupun isu yang terkait dengan fenomena kehidupan masyarakatnya menjadi ciri yang selalu menarik. Dinamika sosial masyarakat pantura baik berkaitan dengan perbedaan nilai, ide atau ideologis dan agama, perbedaan kepentingan pada saat penguasaan kekuasaan/pemilihan kepala daerah, mulai terbatasnya sumber kehidupan yang disertai semakin padatnya penduduk, menjadi penciri yang dapat menyebabkan potensi munculnya konflik di masyarakat.

Salah satu daerah rawan konflik yang berada di wilayah Pantai Utara Jawa Barat yaitu Desa Eretan Wetan. Secara administratif, desa ini terletak di wilayah Kecamatan Kandanghaur Kabupaten Indramayu. Sedangkan, secara geografis desa ini terletak pada jalur transportasi darat pantai utara (jalur pantura). Selain itu, desa ini juga berbatasan langsung dengan Laut Jawa, sehingga mayoritas penduduk berprofesi sebagai nelayan. Kedua hal ini tentunya sangat menguntungkan dan sangat potensial secara ekonomi karena desa ini dapat menjadi jalur transit baik dari laut maupun dari darat. Potensi ini membuat kawasan Eretan (baik Eretan Wetan maupun Eretan Kulon) mendapat predikat sebagai salah satu daerah sentra produksi ikan terbesar di Indramayu, Jawa barat.

Disisi lain, letak desa yang berada di jalur pantura dan berbatasan langsung dengan laut jawa serta akibat dari suhu rata-rata yang tinggi, hal ini mengakibatkan karakteristik penduduk di desa ini menjadi keras dan tempramental. Dari nada bicara pun, rata-rata penduduk menggunakan intonasi yang tinggi ketika berbicara, selain karena kondisi alam yang panas, suara bising dari kendaraan di jalur pantura pun memaksa mereka untuk berbicara dengan nada yang keras. Hal ini menyebabkan wilayah Eretan Wetan menjadi

Sosial Humaniora, Vol. 15, No. 2, Desember 2011: 117126). 
salah satu wilayah rawan konflik di Pantai Utara Jawa Barat.

Di Indonesia masyarakat nelayan merupakan salah satu golongan masyarakat yang dianggap miskin secara absolut, bahkan paling miskin diantara penduduk miskin (the poorest ofthe poor $)^{12}$. Berbagai studi juga telah menunjukkan bahwa kondisi nelayan, khususnya nelayan perikanan skala kecil di Indonesia berada pada tingkat marjinal ${ }^{13}$. Kemudian dari sisi kebijakan, keberpihakan pemerintah selama ini dinilai belum cukup terhadap nelayan ${ }^{14}$. Adanya kebijakan pemerintah yaitu revolusi biru, menyebabkan Pertama, degradasi sumber daya ikan, penurunan daya dukung lingkungan laut dan kerusakan ekosistem. Kedua, menciptakan ketimpangan kelas yang lebar antara pemilik kapal dan buruh nelayan. Ketiga, degradasi hutan mangrove dan pengalihan lahan tambak kepada pemodal. Keempat, konflik ruang di wilayah pesisir yang disebabkan oleh wilayah kegiatan perikanan, pelabuhan, pariwisata, industri maupun kawasan konservasi. Kelima, rendahnya kapasitas sumber daya manusia nelayan sehingga produktivitas mereka juga rendah. Keenam, ketidakadilan struktural yang merugikan nelayan miskin dalam keterbatasan akses modal ${ }^{15}$

Beberapa penelitian telah dilakukan terkait dengan fenomena konflik yang terjadi baik di Jawa Barat secara umumnya, maupun di wilayah Pantura secara khususnya. Penelitian tersebut antara lain penelitian mengenai dasar-dasar konflik di pedesaan (1999); konflik antar warga masyarakat desa (2011); model resolusi konflik berbasis tradisi dan pengetahuan lokal (2012); pengembangan modal sosial sebagai alternatif resolusi konflik (2013); serta model penanganan konflik antar warga di Jawa Barat (2013). Kemudian hasil kajian oleh Soni A. Nulhaqim, dkk. (2013) menjelaskan bahwa masyarakat dan lembagalembaga yang terkait dalam konflik di Jawa Barat masih menganggap konflik antar warga sebagai sesuatu yang lumrah dan dapat

\footnotetext{
12 Mukflihati, 2010).

13 (Kusnadi, 2000; Semedi,2003; Budi,2008)

14 (Tridoyo, 2004)
}

diselesaikan melalui adat istiadat setempat. Penyelesaian kejadian atau peristiwa konflik antar warga tersebut pada umumnya ditangani oleh tokoh masyarakat bukan lembaga yang dimandatkan oleh undang-undang. Peran kelembagaan dalam penanganan konflik antar warga di Jawa Barat cenderung pada fase penyelesaian konflik. Lembaga yang berperan langsung dalam fase penyelesaian konflik tersebut hanya dari pihak kepolisian. Sedangkan, lembaga-lembaga lain lebih memfokuskan pada fase rehabilitasi dan pencegahan konflik.

Penelitian tentang Model Resolusi Konflik komunal masyarakat nelayan di Desa Eretan Wetan Kecamatan Kandanghaur Kabupaten Indramayu ini mengkaji lima aspek konflik mulai dari peristiwa konflik, pemicu konflik, penyebab konflik, dampak dari konflik yang terjadi dan resolusi konflik yang dilakukan untuk mengatasi konflik yang terjadi. Secara khusus, tulisan ini akan membahas lima aspek konflik yang terjadi di Desa Eretan Wetan berdasarkan data yang diperoleh dari informan tokoh pelaku konflik.

Tujuan dari penelitian ini yaitu menggambarkan peta sosial konflik secara komprehensif. Penelitian ini diharapkan memiliki manfaat baik menfaat akademik maupun manfaat praktis. Secara akademik, penelitian ini diharapkan dapat menemukan model resolusi konflik komunal pada daerah maritim dengan pendekatan multi disiplin. Sedangakan secara praktis, penelitian ini diharapkan bermanfaat bagi pemerintah daerah dalam perumusan dan implementasi kebijakan resolusi konflik komunal masyarakat nelayan.

Metode penelitian yang digunakan meliputi jenis deskriptif, pendekatan kualitatif dengan teknik studi kasus serta informan adalah pelaku konflik di Desa Eretan . Teknik pengumpulan data meliputi wawancara mendalam dan observasi non partisipasi serta studi literatur. Pengolahan data meliputi kategori data, display data dan kesimpulan serta analisis.

\footnotetext{
${ }^{15}$ Prihandoko, dkk, Jurnal Makara, Sosial Humaniora, Vol. 15, No. 2, Desember 2011: 117-126)
} 


\section{TINJAUAN PUSTAKA}

Konflik sosial dapat dipahami melalui teori konflik yang merupakan salah satu teori dalam paradigma fakta. Ritzer (1992) menjelaskan bahwa ide pokok dalam teori konflik pada intinya dapat terbagi menjadi tiga pikiran besar : Pertama, bahwa masyarakat selalu berada dalam proses perubahan yang ditandai dengan adanya pertentangan terus menerus diantara unsur-unsurnya. Kedua, setiap elemen akan memberikan sumbangan pada disintegrasi sosial, Ketiga, keteraturan yang terdapat dalam masyarakat itu hanyalah disebabkan oleh adanya tekanan atau pemaksaan kekuasaan dari atas oleh golongan yang berkuasa. Sedangkan teori struktural yang ditentang oleh teori konflik mengandung pula tiga pemikiran utama : Pertama, bahwa masyarakat berada pada kondisi statis, atau tepatnya berada pada kondisi keseimbangan. Kedua, setiap elemen atau institusi memberikan dukungan terhadap stabilitas. Ketiga, anggota masyarakat terikat secara informal oleh norma-norma, nilai-nilai dan moralitas umum.

Galtung (2003:439) kekerasan adalah perampasan kebutuhan; perampasan kebutuhan adalah suatu hal yang serius; salah satu reaksinya adalah kekerasan langsung. Kemudian tindakan kekerasan itu dapat dilakukan secara langsung (kekerasan langsung), dapat juga tidak langsung, yakni melalui proses struktural (kekerasan struktural) dan kultural (kekerasan kultural). Kausal utama kekerasan ialah dari kekerasan kebudayaan yang melalui kekerasan struktural menuju pada kekerasan langsung.

1. Kekerasan langsung

Kekerasan langsung adalah kekerasan yang terlihat secara langsung dalam bentuk kejadian-kejadian atau perbuatan-perbuatan (melukai, merusak bangunan dan simbol-simbol lawan, menyiksa dan membunuh). Kekerasan langsung dapat dibagi menjadi kekerasan verbal dan fisik, dan kekerasan yang merugikan tubuh, pikiran atau jiwa.

2. Kekerasan struktural
Kekerasan struktural adalah kekerasan yang disebabkan oleh struktur sosial. Kekerasan struktural terbagi dalam politis (represif) dan ekonomis (eksploitatif) didukung oleh penetrasi, segmentasi, fragmentasi dan margilitas struktural. Kekerasan kultural.

Kekerasan kultural adalah kekerasan yang terdapat di dalam kultur (budaya) masyarakat atau orang-orang yang hidup di masyarakat. Kekerasan kultural ini menjadi potensi konflik kekerasan, dapat diidentifikasi dalam simbol-simbol budaya seperti: istilahistilah, pribahasa, mitos, benda budaya dan konsep budaya tertentu.

\section{GAMBARAN UMUM LOKASI PENELITIAN}

Desa Eretan Wetan merupakan salah satu desa yang terletak di wilayah Kecamatan Kandanghaur, Kabupaten Indramayu. Secara geografis, letak Desa Eretan Wetan di sebelah utara berbatasan langsung dengan Laut Jawa, sebelah Selatan dan Timur berbatasan dengan Desa Ilir dan sebelah barat berbatasan dengan Desa Eretan Kulon. Pada dasarnya, letak Desa Eretan Wetan sangat strategis, selain karena berbatasan langsung dengan Laut Jawa, desa ini juga terletak di jalur transportasi darat utama negara atau yang lebih dikenal dengan nama jalur pantura. Kedua hal ini tentunya sangat menguntungkan dan sangat potensial secara ekonomi karena desa ini dapat menjadi jalur transit baik dari laut maupun dari darat. Potensi ini membuat kawasan Eretan dikenal sebagai daerah sentra produksi ikan terbesar di Indramayu, Jawa barat.

Desa Eretan Wetan memiliki luas 179,800 ha, yang terdiri dari 49,266 ha wilayah pemukiman dan sisanya berupa lahan persawahan, lahan tambak, ladang garam, tanah pemakaman, dll. Dari luas tersebut, Desa Eretan Wetan terbagi menjadi 5 Rukun Warga dan 21 Rukun Tetangga. Di desa ini Rukun Warga lebih dikenal dengan sebutan Blok. Kelima blok tersebut yaitu Blok Pang-pang I, Blok Pang-pang II, Blok Condong, Blok Prempu I dan Blok Prempu II.Kelima blok tersebut terbagi menjadi dua wilayah yaitu 
wilayah utara dan selatan. Antara wilayah ini dibatas oleh jalur pantura. Wilayah selatan terdiri dari Blok Prempu I dan Prempu II, sedangkan wilayah utara terdiri dari Blok Pang-pang I, Blok Pang-pang II dan Blok Condong. Di sebelah barat desa juga terdapat sebuah sungai yang menjadi batas dengan desa tetangga, yaitu Desa Eretan Kulon.

Berdasarkan Profil Desa Eretan Wetan tahun 2015, Desa Eretan Wetan dihuni oleh 4.598 Kepala Keluarga. Sedangkan jumlah penduduk Desa Eretan Wetan sendiri yaitu berjumlah 11.260 orang, yang terdiri dari 5.731 orang penduduk laki-laki dan 5.529 orang penduduk perempuan. Sedangkan tingkat kepadatan penduduk di desa ini yaitu sebesar 5,72/km2. Berdasarkan data tersebut, Desa Eretan Wetan menjadi desa dengan jumlah penduduk terbesar dan desa dengan kepadatan penduduk paling tinggi di wilayah Kecamatan Kandanghaur.

Sebagian besar penduduk Desa Eretan Wetan menggantungkan hidup pada sektor perikanan dan kelautan, hal ini didukung oleh letak geografis Desa Eretan Wetan sebelah utara yang berbatasan langsung dengan Laut Jawa. Mayoritas penduduk Desa Eretan Wetan berprofesi sebagai nelayan tangkap, bakul ikan/pengusaha ikan, buruh pengolahan ikan, montir perahu, dll. Nelayan merupakan profesi yang paling banyak digeluti oleh penduduk Desa Eretan Wetan. Berdasarkan profil perkembangan desa, pada tahun 2016 jumlah nelayan di desa ini yaitu sebanyak 2.034 orang.

Disisi lain, letak desa yang berada di jalur pantura dan berbatasan langsung dengan laut jawa serta akibat dari suhu rata-rata yang tinggi, hal ini mengakibatkan karakteristik penduduk di desa ini menjadi keras. Dari nada bicara pun, rata-rata penduduk menggunakan intonasi yang tinggi ketika berbicara, selain karena kondisi alam yang panas, suara bising dari kendaraan di jalur pantura pun memaksa mereka untuk berbicara dengan nada yang keras.

\section{HASIL PENELITIAN}

Hasil penelitian ini menyajikan tentang peristiwa konflik, pemicu, penyebab, dampak dan resolusi konflik di masyarakat nelayan Desa Eretan Wetan Kecamatan Kandanghaur Kabupaten Indramayu.

\section{Peristiwa Konflik}

Di Desa Eretan Wetan Kecamatan Kandanghaur Kabupaten Indramayu antara rentang waktu dari tahun 2000 hingga tahun 2016 pernah terjadi beberapa peristiwa konflik di masyarakat baik itu konflik pada masyarakat umum maupun pada masyarakat nelayan. Di Desa Eretan Wetan pernah terjadi konflik yang melibatkan kekerasan. Konflik ini merupakan salah satu konflik besar yang pernah terjadi di Desa Eretan Wetan. Konflik ini terjadi pada saat berlangsungnya acara pesta laut pada bulan Oktober tahun 2000. Konflik pesta laut ini merupakan konflik antara masyarakat dari daerah berbeda yaitu masyarakat Desa Eretan Wetan dan Desa Ilir dimana kedua desa ini merupakan dua desa yang saling bertetangga. Ketika konflik terjadi, kedua desa yang terlibat saling meminta bantuan kepada desa tetangga mereka. Desa Eretan Wetan dibantu oleh Desa Eretan Kulon sedangkan Desa Ilir meminta bantuan kepada Desa Parean. Selain meminta bantuan kepada desa tetangga, kedua desa juga mendatangkan preman-preman atau jawara dari daerah lain seperti dari Bedulan, Cirebon, Karawang dan Banten.

Pada tahun 2013 juga pernah terjadi konflik antar kelompok masyarakat. Konflik antar kelompok masyarakat ini bermula ketika di Desa Eretan Kulon berdiri sebuah pabrik pengolahan ikan yang bernama PT Java Seafood. Sedikitnya telah terjadi tiga kali konflik di masyarakat akibat berdirinya pabrik PT Java Seafood ini. Konflik yang pertama yaitu ketika pembebasan lahan yang akan digunakan untuk lokasi pendirian pabrik. Konflik kedua yaitu pada saat pengurugan tanah dan yang ketiga yaitu konflik pada saat aktivitas pembangunan pabrik baru akan dimulai.

Setelah pabrik beroperasi, konflik kembali terjadi yaitu ketika LSM yang didukung oleh beberapa kelompok masyarakat Desa Eretan Kulon dan Desa Eretan Wetan menganggap bahwa salah satu perusahaan 
tidak pernah memberikan dampak/manfaat positif kepada masyarakat sekitar. Namun disisi lain, aparat pemerintah Desa Eretan Kulon, aparat keamanan hingga karang taruna Desa Eretan Kulon justru mendukung adanya perusahaan tersebut. Hal ini semakin memperkeruh keadaan, karenasalah satu LSM merasa ada yang tidak beres dengan keadaan tersebut. LSM tersebut menganggap bahwa aparat pemerintah dan aparat keamanan telah disuap oleh perusahaan. Dilain pihak, ternyata perusahaan pun menganggap bahwa LSM tersebut hanya ingin mendapatkan keuntungan pribadi dan tidak benar-benar ingin memperjuangkan masyarakat. Terbukti dari salah satu tuntutan LSM agar limbah pabrik dijual kepada mereka untuk kemudian diolah kembali.

Konflik lain yang pernah terjadi di Desa Eretan Wetan yaitu konflik antar pemuda desa. Konflik pemuda ini biasanya terjadi antar kelompok pemuda dari blok yang berbeda. Biasanya di setiap blok terdapat geng-geng atau kelompok-kelompok pemuda. Sering kali geng/kelompok pemuda dari blok yang berbeda tersebut terlibat perkelahian, pengeroyokan atau pun tindakan kekerasan lainnya. Pemuda yang sering terlibat konflik ini pada dasarnya tidak hanya pemuda-pemuda yang diketegorikan remaja atau dewasa. Namun, kasus ini juga sering kali melibatkan anak-anak usia sekolah. Rata-rata usia mereka yaitu antara 12-16 tahun atau antara kelas 5 SD sampai SMP.

Di Desa Eretan Wetan juga pernah terjadi konflik antar keluarga. Konflik antar keluarga ini sebagian besar dilatarbelakangi oleh masalah pembagian harta warisan, penentuan batas tanah dan masalah anak-anak. Lebih lanjut, konflik antar keluarga yang dilatarbelakangi karena masalah anak-anak terjadi ketika ada anak-anak berkelahi dan berujung pada perselisihan orang tua. Hal ini terjadi karena salah satu pihak merasa dirugikan, misalnya karena anaknya mengalami luka-luka dan harus mendapatkan penanganan medis.

Desa Eretan Wetan juga pernah terjadi konflik antar kelompok agama dan kepercayaan. Konflik ini bermula pada tahun 2015, pada saat itu di Desa Eretan Wetan berkembang isu mengenai adanya aliran kepercayaan ISIS. Hingga saat ini ada sekitar tujuh orang warga Desa Eretan Wetan yang diduga sebagai jaringan pengikut ISIS. Berkembangnya isu ini menyebabkan timbul konflik di masyarakat sekitar terutama konflik antara masyarakat sekitar yang mayoritas muslim (NU, Muhammadyah, LDII dan Persis) dengan tujuh orang warga yang diduga pengikut ISIS tersebut. Meskipun konflik yang terjadi hanya sebatas konflik verbal, namun kejadian ini sempat menjadi perhatian berbagai pihak baik masyarakat maupun dari pihak pemerintah dan aparat keamanan.

Isu ISIS ini berkembang ketika ada sekelompok masyarakat lokal yang mendirikan sebuah mesjid di wilayah Blok Pang-pang dua pada bulan Februari 2015. Pendirian mesjid ini dibiayai oleh Pesantren Darussalam Indramayu dan juga didukung oleh pihak luar yang mengatasnamakan organisasi Islam. Pada bulan Juni mesjid selesai dibangun dan mulai banyak jamaah dari daerah lain yang mengikuti pengajian di mesjid tersebut. Pengajian tersebut dilakukan secara rutin setiap bulannya. Pada bulan Juli diadakan sebuah kegiatan pengajian dalam skala besar di mesjid tersebut. Jamaah pun berdatangan dan sebagian besar dari mereka merupakan jamaah dari luar daerah. Pada dasarnya warga sekitar sudah mulai curiga dengan kegiatan pengajian yang diadakan di mesjid tersebut, karena jamaah di mesjid tersebut sebagian besar berasal dari luar daerah. Kecurigaan warga terbukti ketika kegiatan pengajian berlangsung, berdatangan petugas dari BRIMOB, DENSUS dan aparat kepolisian mengepung mesjid tersebut. Namun, meskipun telah dikepung, tidak ada yang ditangkap dari kegiatan tersebut karena orang yang dicari oleh pihak berwajib tidak ada di tempat.

Di akhir tahun 1999, di Desa Eretan Wetan pernah terjadi konflik antar etnis, yaitu etnis Cina dengan etnis pribumi. Konflik ini terjadi karena etnis pribumi merasa tidak dihargai oleh etnis Cina. Misalnya, etnis Cina 
yang sebagian besar merupakan pemilik toko, ketika melayani penduduk pribumi kadang ketika memberikan barang sering dilemparlempar. Selain itu, kadang mereka juga tidak berperilaku ramah kepada pembeli. Hal ini menjadi pemicu kemarahan etnis pribumi. Puncak kemarahan pribumi yaitu ditandai dengan dibakarnya beberapa toko milik etnis Cina dan beberapa toko lainnya dijarah dan dirusak.

Selain termasuk dalam kategori konflik antar etnis, konflik antara etnis Cina dan etnis pribumi ini juga termasuk dalam kategori konflik antara penduduk setempat dengan penduduk pendatang dari luar. Dalam hal ini, etnis pribumi sebagai penduduk setempat dan etnis Cina sebagai penduduk pendatang. Salah satu kasus yang termasuk dalam konflik antara penduduk setempat dengan penduduk pendatang yaitu kasus perkelahian antar pemuda asli Desa Eretan Wetan dengan pemuda pendatang. Dimana pemuda A yang merupakan penduduk asli Desa Eretan Wetan berkelahi dengan pemuda $\mathrm{B}$ yang merupakan penduduk pendatang dari Jawa Timur. Perkelahian ini dipicu karena masalah berebutan perempuan. Pemuda A merasa tersinggung ketika pemuda $\mathrm{B}$ diketahui membawa perempuan yang dimaksud kencan hingga larut malam. Akibatnya, perkelahian antar dua pemuda tersebut tidak dapat dihindarkan.

Selain konflik antar masyarakat, pada tahun 2005 di Desa Eretan Wetan juga pernah terjadi konflik antara masyarakat dengan aparat desa. Konflik ini terkait dengan Program Bantuan Langsung Tunai (BLT). Konflik pembagian BLT ini terjadi karena sebagian anggota masyarakat merasa aparat desa tidak adil dalam pembagian BLT. Masyarakat juga merasa bahwa Program BLT ini belum tepat sasaran. Pasalnya, beberapa anggota masyarakat yang dianggap kurang mampu tidak mendapatkan bantuan, sedangkan masyarakat yang tergolong mampu malah mendapatkan bantuan. Masyarakat juga menganggap bahwa aparat desa lebih mementingkan kepentingan pribadi dibandingkan kepentingan masyarakat. Hal ini terbukti dari banyaknya peserta Program BLT yang merupakan anggota keluarga atau pun saudara dari aparat desa.

Konflik yang juga sering tejadi di Desa Eretan Wetan yaitu konflik pada masyarakat nelayan. Desa Eretan Wetan merupakan salah satu desa yang terletak di pesisir pantai utara. Penduduk Desa Eretan Wetan sebagian besar berprofesi sebagai nelayan. Disebelah utara desa ini terdapat perkampungan nelayan, tempat pelelangan ikan dan juga dermaga tempat kapal-kapal nelayan berlabuh. Nelayan Eretan Wetan ini tidak hanya berasal dari warga lokal, sebagian diantara mereka juga berasal dari luar daerah. Komposisi nelayan di Eretan Wetan yaitu sebanyak $60 \%$ nelayan merupakan penduduk lokal dan $40 \%$ lainnya merupakan nelayan pendatang dari daerah lain. Banyaknya nelayan di Eretan Wetan mengakibatkan sering terjadinya konflik antar masyarakat nelayan.

Konflik antar masyarakat nelayan biasanya terkait dengan perselisihan penggunaan alat tangkap ikan. Konflik ini sangat sering terjadi terutama sejak ada isu bahwa alat tangkap ikan berupa arad, cantrang dan trol akan dilarang penggunaannya oleh Kementrian Perikanan dan Kelautan. Hal ini dikarenakan ketiga alat angkap ikan tersebut merusak ekosistem laut. Jika terus digunakan otomatis jumlah ikan akan semakin berkurang karena habitat mereka akan rusak. Meskipun telah dilarang digunakan, namun beberapa oknum masih saja ada yang tetap menggunakan alat tangkap tersebut. Bagi para nelayan tradisional dan nelayan-nelayan yang telah mentaati peraturan, hal ini tentu sangat merugikan. Hal ini seringkali menjadi pemicu konflik antar nelayan di tengah laut.

Bagi sebagian nelayan yang masih menggunakan alat tangkap tersebut, mereka menganggap bahwa jika alat tangkap ini dilarang atau bahkan dihilangkan, maka hasil tangkapan ikan mereka akan menurun. Sering kali mereka kucing-kucingan dengan petugas berwajib dalam penggunaan alat tangkap ikan ini. Disaat petugas lengah mereka menggunakan alat tangkap ikan yang jelasjelas sudah dilarang penggunaannya. Namun, 
ketika petugas sedang patroli, nelayan seolah mentaati peraturan. Selain konflik antar nelayan yang terkait dengan alat tangkap ikan, seluruh informan juga mengungkapkan bahwa pada masyarakat nelayan juga pernah terjadi konflik antara nelayan dengan masyarakat lain yang bukan nelayan. Konflik jenis ini yaitu konflik pesta laut pada tahun 2000 (telah dibahas pada pembahasan konflik masyarakat umum).

Konflik yang juga sering terjadi pada masyarakat nelayan yaitu konflik antara nelayan dengan juragan. Konflik jenis ini, biasanya konflik timbul karena masalah pembagian hasil yang tidak adil. Nelayan menganggap bahwa juraga selalu mendapatkan hasil/keuntungan yang lebih besar dari pada mereka, dan hal tersebut sangat merugikan nelayan. Selain itu, seringkali nelayan juga merasa dirugikan karena masalah perbekalan dengan harga yang mahal (diatas harga pasar) yang telah dipatok oleh juragan. Disisi lain, jugaran juga menganggap bahwa nelayan sering curang, karena sering kali sebelum berlabuh ke dermaga, hasil tangkapan ikan telah dijual sebagian di daerah lain.

Berikutnys, konflik antara nelayan tradisional dengan konsumen. Konflik ini dipicu oleh sebagian oknum nelayan yang sering melakukan pengurangan timbangan dan permainan harga kepada pemilik industri pengolahan ikan dan juga kepada konsumen. Ketika pemilik industri pengolahan ikan dan konsumen menyadari permainan yang dilakukan oleh nelayan, disitulah konflik terjadi. Terakhir, yaitu konflik antara konsumen (bakul ikan). Konflik ini terjadi ketika konsumen merasa dirugikan karena ikan yang dibeli sering kali berkurang timbangannya akibat petugas pelelangan yang melakukan kuclak (cara mengecek ikan di bakul) dengan cara yang tidak benar.

\section{Pemicu Konflik}

Konflik pada masyarakat umum yang terjadi di Desa Eretan Wetan terjadi karena adanya isu dan masalah yang serius. Konflik pesta laut dipicu oleh rasa kecemburuan sekelompok pemuda Desa Ilir yang merasa tidak diberikan kesempatan oleh warga Desa Eretan Wetan untuk melakukan saweran ketika diadakan hiburan organ tunggal atau dangdutan di acara pesta laut. Mungkin hal ini terlihat sepele, namun bagi masyarakat pantura, saweran dalam sebuah acara hiburan menjadi salah satu kebanggan dan menunjukkan derajat seseorang di masyarakat. Makin lama dan makin banyak uang yang dikeluarkan untuk melakukan saweran, maka makin dihargai dan makin terhormat lah orang yang memberikan saweran tesebut. Selain itu, hal ini juga menjadi kebanggaan tersendiri bagi orang yang bersangkutan. Masalah kecemburuan dalam saweran ini merupakan salah satu pemicu konflik dalam acara pesta laut. Terlebih, antara kedua belah pihak samasama memiliki dendam masa lalu. Selain itu, konflik pun tidak dapat diredam karena diantara kedua belah pihak sebagian besar berada dalam pengaruh minuman keras.

Konflik pemuda sebagian besar dipicu oleh masalah pribadi seperti saling berebut perempuan, tersinggung ketika mengendarai sepeda motor, persaingan dalam perlombaan dan masalah pribadi lainnya. Karena rasa solidaritas yang kuat masalah yang pada awalnya bersifat pribadi berkembang menjadi masalah yang melibatkan kelompok. Selain itu, konflik antar pemuda juga sering kali dipengaruhi oleh minuman keras. Mengkonsumsi minuman keras seolah-olah telah menjadi kebiasaan bagi masyarakat pantura, khususnya masyarakat nelayan. Pengaruh minuman keras ini menyebabkan orang menjadi mudah tersinggung dan berkurangnya kemampuan untuk mengontrol emosi serta berpikir jernih. Hal ini sering kali menyebabkan masalah kecil semakin berkembang menjadi masalah besar.

Konflik antar keluarga sebagian besar dipicu oleh masalah pembagian harta warisan, penentuan batas tanah dan masalah anak-anak. Lebih lanjut, pembagian harta warisan sering kali menjadi pemicu konflik, padahal pihak yang terlibat pada dasarnya saling terikat oleh tali kekeluargaan. Tidak jarang, masalah ini sampai harus melibatkan pihak lain untuk menengahi konflik yang terjadi. Kemudian, 
masalah penentuan batas tanah juga sering menjadi pemicu konflik antar keluarga. Selain itu, konflik antar keluarga salah satunya juga dipicu karena masalah anak-anak, yaitu ketika ada anak-anak yang berkelahi dan berujung pada perselisihan orang tua. Hal ini terjadi karena salah satu pihak merasa dirugikan, misalnya karena anaknya mengalami luka-luka dan harus mendapatkan penanganan medis.

Konflik yang berkaitan dengan isu ISIS pada awalnya juga dipicu oleh adanya dua orang provokator yang mengatasnamakan organisasi Islam. Seperti yang telah dijelaskan sebelumnya, bahwa mereka merupakan wakil dari organisasi Islam dalam pembangunan sebuah mesjid di blok Pang-Pang Dua. Pada awalnya mereka memang tidak secara terangterangan mengaku sebagai pengikut ISIS. Namun, ketika mesjid selesai dibangun dan diadakan pengajian rutin serta kasus pengepungan oleh aparat, rahasia mereka mulai terbongkar. Konflik yang berkaitan dengan isu ISIS ini memang bukan merupakan konflik yang bisa dianggap remeh, terlebih isu ini merupakan isu global yang menjadi perhatian di seluruh penjuru dunia.

Pada konflik pembagian BLT, konflik ini terjadi karena sebagian anggota masyarakat merasa aparat desa tidak adil dalam pembagian BLT tersebut. Masyarakat juga merasa bahwa Program BLT ini belum tepat sasaran. Pasalnya, beberapa anggota masyarakat yang dianggap kurang mampu tidak mendapatkan bantuan, sedangkan masyarakat yang tergolong mampu malah mendapatkan bantuan. Masyarakat juga menganggap bahwa aparat desa lebih mementingkan kepentingan pribadi dibandingkan kepentingan masyarakat. Hal ini terbukti dari banyaknya peserta Program BLT yang merupakan anggota keluarga atau pun saudara dari aparat desa. Hal ini tentunya bukan merupakan hal yang sepele karena hal ini terkait dengan hak masyarakat dalam mendapatkan bantuan dari program pemerintah yang bertujuan untuk meningkatkan kesejahteraan. Namun, hak masyarakat tersebut belum sepenuhnya diberikan kepada masyarakat yang benarbenar berhak mendapatkannya.
Sama halnya seperti yang terjadi pada konflik masyarakat umum, seluruh informan juga menyatakan bahwa sebagian besar konflik pada masyarakat nelayan juga terjadi karena adanya isu dan masalah yang serius. Sebagai contoh, konflik antar nelayan sering kali dipicu karena adanya masalah terkait alat tangkap ikan. Bagi nelayan, alat tangkap ikan ini menjadi penentu seberapa besar hasil tangkapan yang akan mereka dapatkan. Ketika alat tangkap ikan berupa arad, cantrang dan trol dilarang penggunaannya oleh Kementrian Perikanan dan Kelautan para nelayan mau tidak mau harus mematuhi peraturan tersebut. Nelayan diarahkan untuk menggunakan alat tangkap ikan yang lebih ramah lingkungan dan tidak merusak ekosistem laut. Sebagian besar nelayan telah mematuhi peraturan tersebut, namun disisi lain terdapat oknum-oknum nelayan yang masih menggunakan alat tangkap yang dilarang penggunaannya tersebut. Hal ini tentu menjadi masalah yang memicu terjadinya konflik diantara nelayan.

Seluruh informan juga menjelaskan bahwa baik pada konflik masyarakat umum maupun konflik masyarakat nelayan dipicu karena adanya provokator. Sebagai contoh, pada kasus konflik pesta laut yang terjadi di masyarakat umum, sebagian besar masyarakat yang terlibat konflik terbakar emosi dan berani melakukan tindakan kekerasan karena dipancing oleh provokator. Konflik ini pun sebenarnya terjadi karena adanya perkelahian di panggung hiburan antara pemuda dari Desa Eretan Wetan dan pemuda Desa Ilir. Perkelahian tersebut semakin menyebar ketika oknum pemuda yang terlibat perkelahian memprovokasi masyarakat desa asal mereka untuk saling serang. Contoh lain yaitu pada konflik pembagian BLT, pada kasus konflik ini juga tidak terlepas dari adanya provokator. Provokator ini berasal dari kubu oposisi kepala desa yang pada saat itu menjabat. Kubu oposisi pada dasarnya memang selalu mencari-cari kesalahan pemerintahan desa. Isu program BLT ini kemudian diangkat agar masyarakat memberikan penilaian buruk terhadap pemerintahan desa yang sedang menjabat. Hal ini memang berhasil, terlebih pada saat itu 
masyarakat yang sebagian besar merupakan nelayan sangat mudah untuk dihasut.

Sedangkan pada kasus konflik masyarakat nelayan, dalam konflik antar nelayan yang terkait dengan alat tangkap ikan provokator yaitu para oknum nelayan yang masih menggunakan alat tangkap yang dilarang. Ketika ada oknum nelayan yang menggunakan alat tangkap yang dilarang tersebut, sebagian nelayan saling mengikuti untuk menggunakan kembali alat tangkap yang dilarang tersebut. Selain itu, oknum nelayan yang menjadi provokator tersebut juga sering kali menghasut nelayan yang taat peraturan untuk menggunakan alat tangkap yang dilarang. Hal ini lah yang menjadi pemicu konflik alat tangkap ikan pada masyarakat nelayan.

\section{Penyebab Konflik}

Konflik pada masyarakat umum yang terjadi di Desa Eretan Wetan, pada dasarnya terjadi karena adanya rasa ketidakadilan. Pada dasarnya, rasa ketidakadilan ini bentuknya sangat beragam sesuai dengan konflik yang terjadi. Pada konflik pesta laut, rasa ketidakadilan yang dirasakan oleh para pelaku konflik pada awalnya yaitu ketidakadilan dalam memberikan saweran sehingga pada akhirnya menimbulkan kecemburuan diantara kelompok pemuda yang berbeda desa. Sedangkan pada kasus konflik pembagian BLT, masyarakat merasa bahwa aparat desa tidak adil dalam pembagian BLT. Masyarakat juga merasa bahwa Program BLT ini belum tepat sasaran. Pasalnya, beberapa anggota masyarakat yang dianggap kurang mampu tidak mendapatkan bantuan, sedangkan masyarakat yang tergolong mampu malah mendapatkan bantuan.

Pada konflik masyarakat umum, salah satu penyebab konflik lainnya yaitu karena adanya persaingan dalam perebutan kekuasaan politik. Seperti yang telah dijelaskan sebelumnya pada konflik Program BLT terdapat oknum atau provokator yang memancing keributan. Provokator ini berasal dari kubu oposisi kepala desa yang pada saat itu menjabat. Kubu oposisi pada dasarnya memang selalu mencari-cari kesalahan pemerintahan desa. Isu program BLT ini kemudian diangkat agar masyarakat memberikan penilaian buruk terhadap pemerintahan desa yang sedang menjabat. Hal ini memang berhasil, terlebih pada saat itu masyarakat yang sebagian besar merupakan nelayan sangat mudah untuk dihasut.

Sama halnya seperti pada konflik masyarakat umum, seluruh informan juga menyatakan bahwa konflik pada masyarakat nelayan juga disebabkan karena adanya rasa ketidakadilan. Dalam konflik antar nelayan yang terkait dengan masalah alat tangkap ikan, sebagian nelayan merasa tidak adil ketika terdapat oknum-oknum nelayan yang masih menggunakan alat tangkap ikan yang dilarang. Kemudian pada konflik antara nelayan dengan juragan, nelayan merasa tidak adil dalam pembagian hasil tangkapan yang mereka dapatkan. Konflik terkait alat tangkap ikan ini juga disebabkan karena adanya persaingan sumber daya ekonomi. Hal ini diungkapkan oleh seluruh informan yang menyebutkan bahwa sering kali di tengah laut, para nelayan bersaing untuk mendapatkan tangkapan ikan sebanyak-banyaknya. Beberapa oknum nelayan menggunakan cara yang licik yaitu dengan memakai alat tangkap ikan yang telah dilarang oleh pemerintah. Alasannya yaitu, karena ketika menggunakan alat tangkap ikan yang dilarang (arad, cantrang dan trol) hasil tangkapan ikan yang mereka dapatkan sangat banyak. Walaupun disisi lain mereka menutup mata dengan kerusakan ekosistem laut yang diakibatkan oleh penggunaan alat tangkap tersebut.

Terakhir, konflik pada masyarakat nelayan juga disebabkan oleh adanya persoalan di TPI (Tempat Pelelangan Ikan). Konflik ini yaitu konflik yang terjadi antara konsumen (bakul ikan) dengan petugas pelelangan. Konflik ini terjadi ketika konsumen merasa dirugikan karena ikan yang dibeli sering kali berkurang timbangannya akibat petugas pelelangan yang melakukan kuclak (cara mengecek ikan di bakul) dengan cara yang tidak benar. 


\section{Dampak Konflik}

Konflik yang terjadi pada dasarnya telah menimbulkan dampak secara langsung dan tidak langsung kepada masyarakat. Secara garis besar konflik pada masyarakat umum telah menimbulkan kerugian dari segi materi dan non materi, baik itu timbulnya korban luka maupun korban jiwa, kerusakan bangunan, kerusakan lingkungan, timbulnya hambatan ekonomi, berkurangnya rasa kepercayaan masyarakat terhadap pemerintah hingga timbulnya perubahan nilai dan budaya di masyarakat. Konflik yang terjadi mengakibatkan kerusakan lingkungan. Kerusakan lingkungan ini terjadi akibat dampak dari konflik pesta laut. Pada saat konflik pesta laut terjadi, konflik ini diwarnai dengan aksi pembakaran lahan di wilayah Eretan Wetan oleh oknum dari Desa Ilir. Pembakaran lahan ini secara langsung telah merusak lingkungan yang ada di Desa Eretan Wetan.

Berdasarkan data hasil penelitian, konflik yang tejadi di Desa Eretan Wetan juga telah menyebabkan timbulnya korban luka dan korban jiwa. Hal ini diungkapkan oleh seluruh informan baik informan. Konflik yang menyebabkan korban jiwa yaitu konflik pesta laut. Korban berasal dari pihak Desa Ilir. Namun berdasarkan keterangan lain, korban meninggal bukan karena tindakan kekerasan dari pihak Desa Eretan Wetan, namun korban meninggal akibat bentrok dengan petugas keamanan. Konflik pesta laut juga telah menyebabkan korban luka baik luka berat maupun luka ringan. Korban luka ini berasal dari kedua desa. Selain konflik pesta laut, konflik yang juga menyebabkan korban luka yaitu konflik dengan salah satu perusahaan, beberapa orang mengalami luka ringan dan seorang mantan kepala desa Desa Eretan Kulon yang mengalami luka berat.

Selain itu, seluruh informan juga mengatakan bahwa konflik yang terjadi juga mengakibatkan kerusakan bangunan. Konflik yang mengakibatkan kerusakan bangunan ini yaitu konflik pesta laut karena di Desa Eretan Wetan ada sekitar 11 rumah warga yang dibakar dan beberapa lainnya juga rusak akibat dilempari batu. Dari pihak Desa Ilir kerusakan bangunan yaitu berupa pembakaran sebuah gudang dan pabrik garam serta pembakaran 3 unit perahu nelayan. Konflik lain yang juga menyebabkan kerusakan bangunan yaitu konflik Program BLT. Pada konflik ini gedung balai desa dirusak dan dilempari batu oleh warga.

Dampak lain dari konflik yang pernah terjadi yaitu konflik juga telah menimbulkan hambatan ekonomi. Hal ini diungkapkan oleh seluruh informan yang menyatakan bahwa hambatan ekonomi sebagai dampak konflik terjadi terutama selama konflik pesta laut berlangsung. Selama kurang lebih 4-7 hari konflik berlangsung, sebagian besar masyarakat tidak dapat melakukan kegiatan ekonomi atau pun melakukan aktivitas mata pencaharian. Hal ini selain karena situasi yang sedang tidak aman dan kondusif, mereka juga terpaksa untuk terus berjaga untuk mengantisipasi adanya bentrokan susulan. Selain itu, selama konflik berlangsung jalur pantura sepanjang Eretan Wetan hingga Parean lumpuh total tidak dapat dilalui oleh kendaraan, karena ditutup untuk sementara oleh pihak keamanan.

Konflik pesta laut telah menimbulkan perubahan budaya di masyarakat Eretan Wetan. Perubahan budaya ini yaitu pada tahuntahun berikutnya, pesta laut ditiadakan karena alasan keamanan. Selain itu, konflik pesta laut ini juga telah menimbulkan rasa curiga diantara kedua belah pihak. Namun, semakin bertambahnya waktu hal tersebut semakin berkurang

Terakhir, dampak yang timbul dari adanya konflik di Desa Eretan Wetan yaitu berkurangnya kepercayaan masyarakat kepada pemerintahan desa. Berkurangnya kepercayaan masyarakat ini terjadi dalam konflik Program Bantuan Langsung Tunai (BLT) dimana masyarakat menganggap bahwa aparat desa lebih mementingkan kepentingan pribadi dibandingkan kepentingan masyarakat. Hal ini terbukti dari banyaknya peserta Program BLT yang merupakan anggota keluarga atau pun saudara dari aparat desa. 
Sama halnya dengan konflik yang terjadi pada masyarakat umum, konflik pada masyarakat nelayan pun mengakibatkan berbagai dampak. Seluruh informan menyebutkan bahwa konflik yang terjadi pada masyarakat nelayan mengkibatkan aktivitas nelayan dalam mencari ikan menjadi terganggu. Terganggunya aktivitas nelayan dalam mencari ikan ini terutama ketika terjadi konflik antar nelayan terkait dengan konflik alat tangkap ikan. Terlebih ketika konflik ini terjadi ditengah laut, misalnya antara nelayan yang menggunakan alat tangkap berupa jaring tradisional dengan nelayan yang menggunakan alat tangkap berupa arad. Biasanya jika jarak perahu mereka berdekatan, kedua alat tangkap tersebut akan saling tumpang tindih, pada akhirnya jaring tradisional akan rusak/robek karena tertarik oleh arad. Hal ini jelas mengganggu aktivitas nelayan dalam mencari ikan.

Konflik antara nelayan dengan juragan, biasanya fasilitas yang disediakan oleh juragan untuk nelayan akan dibatasi. Bahkan dalam beberapa kasus, ketika nelayan dengan juragan berkonflik sebagian juragan langsung memecat nelayan tersebut, atau di beberapa kasus lainnya nelayan langsung mengundurkan diri dan mencari juragan baru. Konflik antara nelayan dengan juragan juga mengakibatkan perubahan harga jual ikan dari nelayan ke juragan. Biasanya ketika hal ini terjadi, juragan mengambil keuntungan yang lebih banyak dan secara otomatis nelayan pun semakin merasa dirugikan. Seluruh informan pelaku juga menyebutkan bahwa konflik yang terjadi sering kali melahirkan sikap saling mencurigai baik antar sesama nelayan, antara nelayan dengan juragan, antara nelayan dengan konsumen dan antara konsumen dengan petugas pelelangan ikan.

Konflik menyebabkan berkurangnya gotong-royong dan saling membantu diantara sesama nelayan. Seperti misalnya ketika ada nelayan yang sedang menarik kapal untuk berlabuh ke dermaga biasanya siapa pun selalu ikut membantu tanpa diminta. Namun, ketika telah terjadi konflik, nelayan menjadi pilihpilih ketika akan membantu nelayan lainnya.
Dampak konflik jenis ini menunjukkan angka yang relatif kecil karena pada dasarnya dampak jenis ini hanya terjadi pada sebagian kecil nelayan saja.

\section{Resolusi Konflik}

Setiap kali terjadi konflik masyarakat umum di Desa Eretan Wetan selalu selalu dilaporkan kepada pihak berwajib atau pun pihak berwenang setempat. Laporan ketika terjadi konflik ini sesuai dengan jenis dan skala konflik. Jika hanya konflik kecil biasanya cukup dilaporkan kepada RT/RW setempat. Namun, jika konflik dalam skala besar biasanya dilaporkan kepada lurah desa. Lurah desa ini di Desa Eretan Wetan sendiri merupakan aparat desa yang berwenang dalam bidang ketahanan dan keamanan desa. Biasanya, Lurah selalu bekerjasama dengan Babinkantibmas dan pihak kepolisian setempat dalam menangani berbagai konflik yang terjadi di masyarakat.

Dalam tahap upaya penanganan konflik pada saat konflik berlangsung, pihak yang terlibat yaitu mulai dari tokoh masyarakat lokal, pemerintah setempat, pihak keamanan dan anggota masyarakat secara langsung. Pada konflik pesta laut, berdasarkan keterangan dari seluruh informan pelaku, ketika terjadi konflik pihak-pihak berwajib langsung sigap mengamankan. Tokoh masyarakat, tokoh pemerintah setempat (mulai dari RT/RW, desa hingga kecamatan), pihak keamanan (mulai dari polres dan polsek) serta sesama anggota masyarakat pun ikut turun terlibat dalam penanganan konflik ketika konflik berlangsung. Para pihak ini berusaha meredam konflik agar konflik tidak meluas.

Pada konflik yang berkaitan dengan Perusahaan, pihak yang terlibat dalam penanganan konflik pada saat konflik berlangsung yaitu tokoh masyarakat lokal (tokoh adat dan pemuda), pihak keamanan setempat (Polsek Kandanghaur) dan anggota masyarakat. Dalam hal ini pihak pemerintah Desa Eretan Wetan tidak ikut terlibat karena konflik berlangsung di Desa Eretan Kulon. Sedangkan dalam konflik antar pemuda, konflik antar etnis, konflik isu ISIS, konflik 
antar penduduk pendatang seluruh pihak berpartisipasi aktif dalam tahap penanganan pada saat konflik terjadi.

Konflik antar keluarga biasanya pihak pemerintah setempat (RT/RW) yang lebih berperan aktif dalam penanganan pada saat konflik terjadi. Namun, bila konflik antar keluarga tersebut memanjang (biasanya konflik batas tanah) barulah pihak pemerintah desa dan pihak keamanan setempat (polsek) mulai turun tangan. Terakhir, untuk konflik Program BLT seluruh pihak juga ikut terlibat secara aktif dalam penanganan pada saat konflik berlangsung.

Setiap kali terjadi konflik di Desa Eretan Wetan selalu dilakukan upaya penyelesaian masalah. Upaya-upaya ini juga selalu dilakukan dengan jalan perdamaian. Selain itu dalam setiap konflik seluruh pihakpihak berwenang selalu berperan aktif dalam setiap upaya penanganan konflik mulai dari tahap saat konflik berlangsung, tahap penyelesaian konflik juga pada tahap rehabilitasi konflik. Pada tahap rehabilitasi konflik para pihak yang berwenang selalu berusaha untuk melakukan berbagai upaya kontrol sosial agar konflik tidak terulang kembali. Selain itu, setiap pihak berwenang juga berupaya untuk membentuk sebuah konsensus di masyarakat dengan berbagai cara.

Dalam tahap penyelesaian pasca konflik, pada konflik pesta laut penyelesaian pasca konflik dilakukan melalui upaya mediasi antara kedua desa yang difasilitasi oleh pihak kepolisian setempat yaitu Polsek Kandanghaur dan bekerja sama dengan Polres Indramayu. Upaya mediasi ini dilakukan dengan mempertemukan seluruh pihak-pihak berwajib kedua desa untuk melakukan perjanjian damai. Perjanjian damai ini ditandai dengan ditandatanganinya surat perjanjian damai oleh pihak-pihak berwajib kedua desa.

Untuk Konflik dengan salah satu perusahaan, pihak yang terlibat dalam tahap penyelesaian pasca konflik yaitu perwakilan perusahaan, perwakilan LSM, tokoh masyarakat lokal (tokoh adat dan pemuda), pihak keamanan setempat (Polsek
Kandanghaur) dan anggota masyarakat. Dalam hal ini pihak pemerintah Desa Eretan Wetan tidak ikut terlibat karena konflik berlangsung di Desa Eretan Kulon. Dalam tahap penyelesaian pasca konflik ini seluruh pihak bertemu secara langsung untuk melakukan negosiasi. Setelah dilakukan upaya negosiasi, seluruh pihak sepakat bahwa tuntutan yang dilakukan oleh Salah satu LSM dicabut kembali. Pada akhirnya seluruh pihak berdamai dan hingga saat ini perusahaan dapat melakukan kegiatan produksi dan operasionalnya dengan aman.

Pada konflik antar pemuda, pihak yang terlibat dalam tahap penyelesaian pasca konflik yaitu tokoh masyarakat, pemerintah setempat mulai dari RT/RW dan pemerintah desa yang diwakili oleh lurah, pihak keamanan dan masyarakat. Keterlibatan pemerintah desa dan aparat keamanan biasanya ketika konflik antar pemuda ini sampai mengarah pada tindakan kekerasan atau perkelahian yang melibatkan banyak orang. Jika konflik antar pemuda hanya sebatas konflik verbal atau konflik kecil lainnya, biasanya hanya ditangani oleh masyarakat, tokoh masyarakat dan pengurus RT/RW.

Pihak yang terlibat dalam penyelesaian pasca konflik antar keluarga biasanya dilakukan oleh pemerintahan setempat mulai dari RT/RW dan pemerintahan desa, aparat keamanan dan masyarakat secara langsung. Untuk konflik antar keluarga dalam skala kecil seperti konflik antar keluarga yang disebabkan oleh masalah perkelahian antar anak-anak biasanya diselesaikan di tingkat $\mathrm{RT} / \mathrm{RW}$ setempat, dengan catatan jika kedua keluarga yang terlibat konflik ini masih dalam satu lingkungan RW. Namun jika sudah berbeda RW, konflik diselesaikan dengan bantuan Lurah desa dan aparat keamanan atau Babinkamtibmas. Kemudian jika konflik antar keluarga tersebut karena masalah batas tanah atau warisan biasanya seluruh pihak tersebut terlibat dalam tahap penyelesaian pasca konflik. Hal ini didasari karena pada dasarnya konflik yang diakibatkan oleh masalah batas tanah dan warisan biasanya konflik besar dan memerlukan penyelesaian yang rumit. Pada 
konflik antar etnis, konflik isu ISIS, konflik antar penduduk pendatang, konflik Program BLT seluruh pihak mulai dari tokoh masyarakat, pemerintah setempat, pihak keamanan dan anggota masyarakat bersamasama ikut terlibat secara aktif dalam tahap penyelesaian pasca konflik.

Pelaku menyebutkan bahwa pasca konflik pesta laut terjadi, pemerintah dan pihak keamanan setempat melakukan berbagai upaya kontrol sosial agar konflik tidak terulang kembali. Beberapa upaya yang dilakukan yaitu pertama pada tahun berikutnya, pihak pemerintah kecamatan, kepolisian serta koramil melarang diadakannya pesta laut karena alasan keamanan. Namun, pada tahun 2003 juru mudi dan ABK menuntut diadakan kembali pesta laut. Akhirnya panitia dan tokoh masyarakat berinisiatif membuat sebuah peraturan. Sekitar 19 juru mudi yang berasal dari Desa Ilir dipanggil dan diadakanlah perjanjian antara panitia dengan juru mudi tersebut. Juru mudi diminta membuat perjanjian bahwa mereka sanggup menjamin pesta laut yang akan diadakan akan berjalan dengan lancar tanpa ada keributan. Perjanjian dilakukan dengan menandatangani surat perjanjian hitam diatas putih. Setelah itu, juru mudi tersebut juga mensosialisasikan kepada para pemuda desa bahwa mereka telah membuat perjanjian. Bilamana ada pemuda desa yang memancing keributan, juru mudi lah yang akan bertindak.

Kedua, ketika diadakan turnamen sepak bola antar desa, Desa Eretan Wetan dan Desa Ilir tidak pernah dipertemukan. Hal ini guna menghindari kembali terjadinya konflik. Ketiga, pihak kepolisian dari Polsek Kandanghaur secara rutin melakukan patroli ke wilayah-wilayah yang dianggap rawan konflik. Keempat, pihak kepolisian juga secara rutin melakukan penyuluhan dan sosialisasi terkait keamanan dan ketertiban lingkungan. Terakhir, upaya ini juga dilakukan dengan melakukan kampanye terkait keamanan dan ketertiban dengan menyebarkan spanduk yang berisi himbauan dan ajakan kepada masyarakat agar selalu menjaga ketertiban dan keamanan lingkungan.
Berbagai upaya yang dilakukan dalam resolusi konflik kasus pesta laut ini dapat dikatakan berhasil. Hal ini terbukti hingga saat ini tidak pernah terjadi lagi kasus serupa di wilayah Desa Eretan Wetan. Bahkan saat ini masyarakat dari kedua desa dapat saling berdampingan dan hidup secara rukun. Hal ini diungkapkan oleh seluruh informan pelaku.

Pada konflik kepercayaan atau konflik isu ISIS, seluruh pihak mulai dari tokoh masyarakat, pemerintah setempat, pihak keamanan dan anggota masyarakat bersamasama ikut terlibat dalam tahap rehabilitasi konflik. Upaya ini dilakukan agar tidak terjadinya perpecahan antar anggota masyarakat. Seluruh pihak juga bersama-sama mengawasi dan mengontrol setiap kegiatan yang dilakukan di mesjid tersebut. Pada akhirnya, seluruh anggota masyarakat bisa saling menghormati kepercayaan masingmasing dan dapat melaksanakan ibadah sesuai dengan kepercayaan masing-masing.

Untuk konflik yang terjadi akibat program BLT, pihak yang terlibat dalam rehabilitasi konflik yaitu pemerintah setempat dan aparat keamanan. Pihak pemerintah setempat akhirnya memberikan dana BLT kepada seluruh masyarakat yang menuntut untuk diberi bantuan. Caranya yaitu dengan memotong sebagian dana BLT dari peserta terdaftar untuk kemudian dibagikan kepada masyarakat yang menuntut bantuan. Hal ini juga dilakukan dibawah pengawasan aparat pemerintah. Cara ini terbukti efektif, karena masyarakat merasa bahwa pemerintah desa telah adil dan konflik pun tidak terulang kembali.

Secara garis besar, upaya yang dilakukan dalam penanganan sebuah konflik di Desa Eretan Wetan yaitu dilakukan melalui upaya non ligitasi baik itu pada konflik masyarakat umum maupun konflik masyarakat nelayan. Upaya non ligitasi yang sering dilakukan yaitu upaya mediasi seperti yang dilakukan dalam penanganan konflik pesta laut, konfik antar pemuda, konflik ISIS, konflik penduduk setempat dengan pendatang, konflik antar pendatang, dan pada konflik antar 
nelayan dan konglik nelayan dengan petugas TPI.

Pada konflik masyarakat umum, upaya mediasi ini yaitu dilakukan dengan mengikutsertakan pihak ketiga dalam penyelesaian konflik sebagai penasihat. Biasanya pihak ketiga ini berasal dari aparat pemerintah setempat mulai dari RT/RW, pemerintahan desa dan pemerintahan kecamatan, kemudian juga Babinkantibmas dan aparat keamanan setempat mulai dari Polsek Kandanghaur dan Polres Indramayu. Sedangkan pada konflik masyarakat nelayan, upaya mediasi ini yaitu difasilitasi oleh pihak keamanan setempat yang terdiri dari organisasi nelayan (KUD), Pangkalan Angkatan Laut (Lanal) TNI AL, Syahbandar serta Polisi Perairan dan Udara (Polairud).

Upaya non ligitasi lainnya yaitu upaya negosiasi yang dilakukan dalam penanganan konflik dengan perusahaan, konflik antar keluarga, konflik antar nelayan dan konflik program BLT. Upaya negosiasi ini dilakukan dengan mengadakan perundingan antara pihak yang berselisih untuk menyelesaikan konflik dengan jalan damai. Selain upaya non ligitasi, upaya ligitasi atau penanganan konflik melalui jalur pengadilan juga pernah dilakukan yaitu pada konflik antar keluarga yang diakibatkan oleh masalah batas tanah dan pembagian warisan.

Pada kasus konflik masyarakat nelayan, biasanya konflik ditangani oleh beberapa pihak berwajib yaitu organisasi nelayan (KUD), Pangkalan Angkatan Laut (Lanal) TNI AL, Syahbandar serta Polisi Perairan dan Udara (Polairud). Ke-empat pihak tersebut merupakan pihak-pihak yang bertanggung jawab ketika terjadi konflik pada masyarakat nelayan. Dalam penanganan konflik nelayan, menurut seluruh informan pelaku, pemerintah seperti desa atau kecamatan sejauh ini belum pernah dilibatkan. Hal ini dikarenakan konflik yang terjadi masih bisa diselesaikan oleh keempat pihak yang telah disebutkan sebelumnya. Pemerintah baru akan bertindak jika konflik yang terjadi mulai meluas kepada masyarakat umum. Ketika terjadi konflik, nelayan biasanya langsung melapor kepada pihak berwajib tersebut. Biasanya pihak-pihak tersebut langsung memanggil pihak yang terlibat konflik untuk didamaikan. Cara yang dilakukan yaitu dengan memediasi kedua belah pihak atau mengajak kedua belah pihak yang terlibat konflik untuk melakukan musyawarah sehingga lahirlah kesepakatan bersama. Namun, disisi lain menurut keterangan dari seluruh informan pelaku pada kasus konflik di masyarakat nelayan, karena sebagian besar konflik yang sering terjadi adalah konflik pribadi, maka biasanya penyelesaiannya pun bersifat pribadi. Dengan kata lain, penyelesaian konflik tidak melibatkan pihak-pihak lain. Cukup penyelesaian antar individu yang berkonflik atau berselisih.

Disisi lain, untuk konflik antar nelayan dan konflik antara nelayan dengan petugas tempat pelelangan ikan biasanya upaya penanganan konflik saat konflik berlangsung dibantu dan difasilitasi oleh pihak keamanan setempat. Dalam hal ini pihak-pihak tersebut yaitu organisasi nelayan (KUD), Pangkalan Angkatan Laut (Lanal) TNI AL, Syahbandar serta Polisi Perairan dan Udara (Polairud).

Sama halnya dengan tahap penanganan saat konflik berlangsung, pada tahap penyelesaian pasca konflik pun sebagian besar dilakukan secara pribadi, karena konflik yang terjadi pun sebagian besar bersifat pribadi. Sedangkan, untuk konflik antar nelayan dan konflik antara nelayan dengan petugas tempat pelelangan ikan biasanya pada tahap penyelesaian pasca konflik dilakukan oleh pihak keamanan setempat. Dalam hal ini pihak-pihak tersebut yaitu organisasi nelayan (KUD), Pangkalan Angkatan Laut (Lanal) TNI AL, Syahbandar serta Polisi Perairan dan Udara (Polairud).

Selain melakukan resolusi konflik, menurut seluruh informan pelaku keempat pihak tersebut juga selalu melakukan program dan berbagai upaya kontrol sosial untuk mencegah terjadinya konflik pada masyarakat nelayan. Seperti misalnya kegiatan patroli rutin di sekitar perairan Laut Jawa yang dilakukan oleh TNI AL dan Polairud. Kemudian juga melakukan sosialisasi 
peraturan pemerintah yang berkaitan dengan kelautan dan perikanan termasuk sosialisasi yang berkaitan dengan alat tangkap ikan. Selain itu, KUD juga selalu mengagendakan pertemuan rutin dan rapat anggota KUD Misaya Mina.

Rehabilitasi konflik biasanya dilakukan pada konflik antar nelayan dan konflik nelayan dengan petugas TPI. Upaya yang dilakukan seperti misalnya kegiatan patroli rutin di sekitar perairan Laut Jawa yang dilakukan oleh TNI AL dan Polairud. Kemudian juga melakukan sosialisasi peraturan pemerintah yang berkaitan dengan kelautan dan perikanan termasuk sosialisasi yang berkaitan dengan alat tangkap ikan. Selain itu, KUD juga selalu mengagendakan pertemuan rutin dan rapat anggota KUD.

Sejauh ini dalam penyelesaian konflik di masyarakat nelayan belum pernah sampai ke jalur pengadilan (ligitasi). Seperti yang telah dijelaskan sebelumnya, bahwa konflik di masyarakat nelayan sebagian besar merupakan konflik yang bersifat individu, maka penyelesaian konflik sebagian besar dilakukan melalui upaya negosiasi diantara kedua belah pihak yang terlibat konflik. Selain itu, upaya non ligitasi yang juga pernah dilakukan yaitu upaya mediasi pada konflik antar nelayan dan konflik nelayan dengan petugas TPI. Upaya mediasi ini yaitu difasilitasi oleh pihak keamanan setempat yang terdiri dari organisasi nelayan (KU), Pangkalan Angkatan Laut (Lanal) TNI AL, Syahbandar serta Polisi Perairan dan Udara (Polairud).

\section{KESIMPULAN}

Berdasarkan pembahasan diatas dapat dikemukakan simpulan sebagai berikut :

Peristiwa konflik, Di Desa Eretan Wetan Kec. Kandanghaur Kab. Indramayu telah terjadi beberapa konflik baik di masyarakat umum maupun di masyarakat nelayan. Konflik ini juga terjadi baik konflik besar maupun konflik dalam skala kecil. Konflik yang melibatkan kekerasan yaitu diantaranya konflik pesta laut pada tahun 2000, konflik dengan suatu perusahaan, konflik antar pemuda, konflik dengan salah satu etnis, dan konflik masyarakat dengan aparat pemerintah yang disebabkan karena pembagian BLT pada tahun 2005. Sementara itu konflik yang tanpa kekerasan yaitu konflik antar keluarga dan konflik kepercayaan yang terkait isu ISIS pada tahun 2015. Sedangkan konflik pada masyarakat nelayan ini sangat beragam mulai dari konflik antar masyarakat nelayan, konflik antara nelayan dengan juragan, konflik nelayan dengan konsumen dan konflik nelayan dengan tempat pelelangan ikan.

Pemicu konflik, konflik yang terjadi di Desa Eretan Wetan baik dalam konflik masyarakat umum maupun konflik masyarakat nelayan dipicu oleh adanya isu dan masalah yang serius sehingga akhirnya menimbulkan konflik di masyarakat. Konflik dipicu karena adanya provokator.

Penyebab konflik, konflik yang terjadi di masyarakat umum sebagian besar disebabkan karena adanya rasa ketidakadilan yang dialami oleh para pelaku konflik. Selain itu, konflik juga disebabkan karena adanya persaingan dalam perebutan kekuasaan. Dalam hal ini yaitu perebutan kekuasaan terkait dengan pilkades. Sedangkan dalam konflik masyarakat nelayan, konflik juga disebabkan karena adanya rasa ketidakadilan yang dialami oleh para pelaku konflik. Selain itu, konflik pada masyarakat nelayan juga disebabkan karena adanya persaingan sumber daya ekonomi. Terakhir, konflik pada masyarakat nelayan disebabkan oleh adanya persoalan di TPI (Tempat Pelelangan Ikan).

Dampak konflik, Konflik yang terjadi pada dasarnya telah menimbulkan dampak secara langsung dan tidak langsung kepada masyarakat. Konflik yang terjadi pada masyarakat umum telah menimbulkan kerugian dari segi materi dan non materi, baik itu timbulnya korban luka maupun korban jiwa, kerusakan bangunan, kerusakan lingkungan, timbulnya hambatan ekonomi, berkurangnya rasa kepercayaan masyarakat terhadap pemerintah hingga timbulnya perubahan nilai dan budaya di masyarakat. 
Kemudian, dampak konflik masyarakat nelayan meliputi terganggunya aktivitas nelayan dalam mencari ikan, terganggungunya hubungan nelayann dengan juragan,serta terganggunya gotong-royong diantara sesama nelayan.

Resolusi konflik, konflik di Desa Eretan Wetan selalu selalu dilaporkan kepada pihak berwajib atau pun pihak berwenang setempat. Laporan ketika terjadi konflik ini sesuai dengan jenis dan skala konflik. Pada dasarnya setiap kali terjadi konflik di Desa Eretan Wetan selalu dilakukan upaya penyelesaian masalah baik secara hokum maupun melalui musyawarah dengan adanya pihak yang menjadi mediatornya serta negosiasi pihak-pihak yang berkonflik. Pihak yang terlibat dalam penanganan konflik yaitu tokoh masyarakat lokal, pemerintah setempat, dan pihak keamanan baik TNI maupun kepolisian, serta organisasi nelayan.

\section{DAFTAR PUSTAKA}

\section{Buku}

Braithwaite, John. 2001. Restorative Justice and Responsive Regulation, Oxford University Press, New York.

Coser Lewis A. 1959. The Function of Social Conflict. Glancoe. The Free Press

Dahrendorf. Ralf. 1959. Class and Class Conflict in Industrial Society. Stndford Calif. Stndford Univ. Press

Fisher, Simon, et.al (2000). Mengelola Konflik, Keterampilan dan Strategi untuk Bertindak (Alih bahasa : S.N. Kartikasari dkk). Jakarta : The Britis Council Coser Lewis A. 1959. The Function of Social Conflict. Glancoe. The Free Press.

Katherine S. Williams. 2001. Textbook on Criminology. Fourth Edition. Oxford University Press.

Michael Braswell, Johm Fuller, dan Bo Lozoff. 2015. Corrections, Peacemaking, and Restorative Justice: Transforming Individuals and Institutions. Routledge, USA.
Tim Newburn. 2007. Criminology. Willan Publishing. Oregon. USA.

Vold, George B., Thomas J, Bernard, dan Jeffrey B. Snipes. 2002. Theoretical Criminology, Fifth Edition, Oxford University Press, New York.

Wallace and Wolf .2005. Contemporary Sociological Theory. Prentice Hall Upper Sadle River. New Yersey.

White, Rob \& Fiona Haines. 1996. Crime and Criminology: An Introduction. Oxford University Press.

Zastrow, Charles. 2010. Introduction to Social Work and Social Welfare, Empowering People Tenth Edition. Canada : Brooks/cole Cengage Learning.

\section{Jurnal}

Paul M. Klenowski, Peacemaking Criminology: Etiology of Crime or Philosophy of Life, Contemporary Justice Review, Vo. 12, No. 2, June 2009.

Prihandoko dkk. Makara, Sosial Humaniora, Vol. 15, No. 2, Desember 2011: 117126

\section{Penelitian}

Nulhaqim, Soni A, dkk. 2013. Model Penanganan Konflik Antar Warga Di Jawa Barat. Dibiayai oleh : Direktorat Penelitian dan Pengabdian Kepada Masyarakat Direktorat Jenderal Pendidikan Tinggi Kementerian Pendidikan dan Kebudayaan

\section{Peaturan Perundangan}

Undang-Undang Republik Indonesia No 11 tahun 2009 tentang Kesejahteraan Sosial UU No. 7 Tahun 2012 tentang Penanganan Konflik Sosial

\section{Sumber lainnya:}

Anonim, Pamanukan Daerah Berpotensi Konflik Sosial di Subang, http://targetabloid.co.id/berita/3785pamanukan-daerah-berpontensikonflik-sosial-di-subang, diunduh pada tanggal 5 April 2015. 
Sisi Kultural Masyarakat Pantura Berpotensi Konflik, http://www.pikiranrakyat.com/node/116029, diunduh pada tanggal 5 April 2015. 